\title{
Furs and Skins
}

\section{Barrow Hepburn \& Gale Ltd}

Bardens, D., Everything in Leather: The Story of Barrow Hepburn \& Gale Ltd (1948). 89 pp.

Goad, Rigg \& Co.

The History of Goad, Rigg \& Company (The Company, 1952). $15 \mathrm{pp}$.

Martin (C. W.) \& Sons Ltd

— Under Eight Monarchs 1823-1953: The History of a London Fur Dressing Firm (The Company, 1953). 69 pp.

\section{Poland (P. R.) \& Son Ltd}

Purvis, W. F., Nine Generations of Fur Trading (The Firm, 1951). $16 \mathrm{pp}$.

\section{Smith (George) \& Sons Ltd}

A Short History of the Firm of George Smith \& Sons of Old Bailey, Gough Square and Watling Street, Wholesale Furriers (The Firm, 1935). 22 pp. 